\title{
Three new species and a new combination of Triblidium
}

\author{
Tu Lv', Cheng-Lin Hou', Peter R. Johnston ${ }^{2}$
}

I College of Life Science, Capital Normal University, Xisanhuanbeilu 105, Haidian, Beijing 100048, China

2 Manaaki Whenua Landcare Research, Private Bag 92170, Auckland 1142, New Zealand

Corresponding author: Cheng-Lin Hou (chenglin-hou@cnu.edu.cn)

Academic editor: D. Haelewaters | Received 17 September 2019|Accepted 18 October 2019|Published 31 October 2019

Citation: Lv T, Hou C-L, Johnston PR (2019) Three new species and a new combination of Triblidium. MycoKeys 60: 1-15. https://doi.org/10.3897/mycokeys.60.46645

\begin{abstract}
Triblidiaceae (Rhytismatales) currently consists of two genera: Triblidium and Huangshania. Triblidium is the type genus and is characterised by melanized apothecia that occur scattered or in small clusters on the substratum, cleistohymenial (opening in the mesohymenial phase), inamyloid thin-walled asci and hyaline muriform ascospores. Before this study, only the type species, Triblidium caliciiforme, had DNA sequences in the NCBI GenBank. In this study, six specimens of Triblidium were collected from China and France and new ITS, mtSSU, LSU and RPB2 sequences were generated. Our molecular phylogenetic analysis and morphological study demonstrated three new species of Triblidium, which are formally described here: T. hubeiense, T. rostriforme and T. yunnanense. Additionally, our results indicated that Huangshania that was considered to be distinct from Triblidium because of its elongated, transversely-septate ascospores, is congeneric with Triblidium. Therefore, we have placed Huangshania in synonymy under Triblidium, rendering Triblidiaceae a monotypic family.
\end{abstract}

\section{Keywords}

Huangshania, phylogenetic, taxonomy, Triblidiaceae, three new taxa, muriform ascospores

\section{Introduction}

Triblidium Rebent.: Fr. is the type genus of Triblidiaceae Rehm (Rehm 1888-1896, 1912), which includes presumed saprobes on the bark of Pinaceae, Ericaceae and Fagaceae (Magnes 1997). In his monograph of the family, Magnes (1997) speculated that some species may exist in an endophytic state. Species of Triblidium are well documented in Europe, but they are poorly understood in Asia and America (Magnes

Copyright Tu Lv et al. This is an open access article distributed under the terms of the Creative Commons Attribution License (CC BY 4.0), which permits unrestricted use, distribution, and reproduction in any medium, provided the original author and source are credited. 
1997). Magnes (1997) revised Triblidium and accepted amongst the many included species only four species and one subspecies.

A history of Triblidiaceae is given in Karakehian et al. (2019). In brief, Magnes (1997) placed Triblidiaceae in Rhytismatales and treated Triblidiales as a synonym of Rhytismatales. Recent five-locus (Prieto et al. 2019) and 15-locus (Johnston et al. 2019) phylogeny analyses found high support for Pseudographis (Triblidiaceae) within Rhytismatales. The results of a three-gene phylogenetic analysis with expanded sampling by Karakehian et al. (2019) supported Magnes classification and the authors emended Triblidiaceae to include Triblidium and Huangshania.

We conducted a morphological analysis of a specimen of T. caliciiforme Rebent.: Fr., the type species of Triblidium and additional collections of Triblidiaceae. Phylogenetic relationships were inferred based on internal transcribed spacer (ITS), nuclear large subunit ribosomal DNA (LSU), mitochondrial small subunit ribosomal DNA (mtSSU) and the second largest subunit of RNA polymerase II (RPB2) gene.

\section{Materials and methods}

\section{Morphological studies and isolation}

A specimen of Triblidium caliciiforme was collected in France in June 2012 on Quercus sp. Other specimens were collected in China between 2006 and 2018. Mature dried ascomata were selected for morphological observation. All observations were made from dead herbarium material. Gross morphology was observed and photographed with a dissecting microscope (Nikon SMZ-1000). Standardised colour values matching the colour of the hymenium were taken from https://www.colorhexa.com/. Microscopic preparations were observed in distilled water, Lugol's solution (IKI), 5\% potassium hydroxide $(\mathrm{KOH})$ and lactophenol solution. Methods for morphological analysis follow Hou et al. (2009). Measurements of asci and ascospores were made in distilled water in 2019. For each structure, at least 25 measurements were recorded. Microphotographs were obtained using an Olympus BX51 compound microscope. Specimens are deposited in the Herbarium of the College of Life Science, Capital Normal University, Beijing, China (BJTC). Fresh specimens were used to obtain cultures directly from single ascoma, after washing and surface sterilisation, as follows: $75 \%$ ethanol for $10 \mathrm{~s}, 10 \%$ sodium hypochlorite for $3 \mathrm{~min}$, washing in sterile water three times. The single ascoma was dried in sterilised tissue paper, placed on potato dextrose agar (PDA) with $50 \mathrm{mg} / \mathrm{l}$ chloramphenicol and incubated at room temperature $\left(25^{\circ} \mathrm{C} \pm 3{ }^{\circ} \mathrm{C}\right)$. We were unable to obtain cultures from ascomata after a month.

\section{DNA extraction and PCR amplification}

Genomic DNA was extracted from ascomata using NuClean Plant Genomic DNA Kit (CWBIO, China), following the manufacturer's instructions and stored at $-20^{\circ} \mathrm{C}$. Se- 
quences of ITS, LSU, mtSSU and RPB2 were obtained. PCR amplifications were undertaken using primers ITS1F/ITS4 for ITS, mrSSU1/mrSSU3R for mtSSU, LR0R/ LR5 for LSU and 5F/7CR for RPB2 (Vigalys and Hester 1990, White et al. 1990, Gardes and Bruns 1993, Rehner and Samuels 1994, Liu et al. 1999, Zoller et al. 1999). ITS, mtSSU and LSU PCR procedures in $25 \mu \mathrm{l}$ reactions were carried out as outlined by Hou et al. (2009). PCR amplification of the RPB2 region was undertaken with an initial denaturation at $95^{\circ} \mathrm{C}$ for $5 \mathrm{~min}$, followed by 35 cycles of denaturation at $95^{\circ} \mathrm{C}$ for $60 \mathrm{~s}$, annealing at $55^{\circ} \mathrm{C}$ for $60 \mathrm{~s}$ and elongation at $72{ }^{\circ} \mathrm{C}$ for $2 \mathrm{~min}$ and a final elongation at $72^{\circ} \mathrm{C}$ for $10 \mathrm{~min}$ (Liu et al. 1999). The PCR products were purified, sequenced and edited by ZhongKe Xilin Biotechnology Co., Ltd. (Beijing, China). The new sequences were submitted to the NCBI GenBank database. Their accession numbers, as well as those for other ITS, LSU, mtSSU and RPB2 sequences downloaded from GenBank, are given in Table 1.

Table I. Species and GenBank accession numbers of the sequences analysed in this study. "-” indicates data unavailable. Sequences generated for this study are in boldface.

\begin{tabular}{|c|c|c|c|c|c|}
\hline Species & Voucher and strain & ITS & LSU & mtSSU & RPB2 \\
\hline Bisporella citrina & AFTOL-ID 1301 & - & FJ176871 & FJ190632 & FJ238354 \\
\hline Coccomyces dentatus & AFTOL-ID 147 & DQ491499 & AY544657 & AY544736 & DQ247789 \\
\hline Coccomyces lauraceus & ICMP:18319 & - & HM140504 & HM143781 & - \\
\hline Coccomyces tumidus & Lantz 396 (UPS) & - & HM140510 & HM143787 & - \\
\hline Colpoma quercinum & Lantz 368 (UPS) & - & HM140513 & HM143789 & - \\
\hline Cryptomyces maximus & Lantz \& Minter 424 (UPS) & - & HM140514 & HM143790 & - \\
\hline Cudonia circinans & Lantz \& Widen 402 (UPS) & - & HM140515 & HM143791 & - \\
\hline Huangshania verrucosa & UME-29336a & MK751793 & MK751802 & MK751716 & - \\
\hline Hypoderma rubi & ICMP:17339 & JF683419 & HM140526 & HM143801 & - \\
\hline Hypohelion scirpinum & Lantz 394 (UPS) & - & HM140531 & HM143806 & - \\
\hline Lirula macrospora & Isolate 13 & HQ902159 & HQ902152 & - & - \\
\hline Lophodermium eucalypti & ICMP:16796 & EF191235 & HM140541 & HM143817 & - \\
\hline Neofabraea malicorticis & AFTOL-ID 149 & - & AY544662 & AY544751 & - \\
\hline Pseudographis elatina & GJO-0090016 & MK751794 & MK751803 & MK751717 & - \\
\hline \multirow[t]{2}{*}{ Pseudographis pinicola } & FH-18061706 & MK751795 & MK751804 & MK751718 & - \\
\hline & FH-NB842 & MK751796 & MK751805 & MK751719 & - \\
\hline Sporomega degenerans & Lantz 367 (UPS) & - & HM140567 & HM143839 & - \\
\hline Spathularia flavida & KUS-F52331 & JN033405 & JN086708 & JN086781 & JN086859 \\
\hline Therrya abieticola & HOU447A & KP322574 & KР322579 & KP322587 & - \\
\hline \multirow[t]{5}{*}{ Triblidium caliciiforme } & FH-15071105 & MK751797 & MK751806 & MK751720 & - \\
\hline & CUP-18080101 & MK751798 & MK751807 & MK751721 & - \\
\hline & E-00012551 & MK751799 & MK751808 & MK751722 & - \\
\hline & E-00012552 & MK751800 & MK751809 & MK751723 & - \\
\hline & GJO-0088904 & MK751801 & MK751810 & MK751724 & - \\
\hline Triblidium caliciiforme & HOU1053 & MN519485 & MN540636 & MN538985 & MN547962 \\
\hline Triblidium hubeiense & HOU1350A & MN541813 & MN541811 & MN541828 & MN565260 \\
\hline \multirow[t]{2}{*}{ Triblidium rostriforme } & HOU851A & MN541815 & MN541820 & MN541821 & MN565263 \\
\hline & HOU889 & MN541822 & MN541817 & MN541839 & MN565262 \\
\hline \multirow[t]{3}{*}{ Triblidium yunnanense } & HOU470A & MN541818 & MN541819 & MN541810 & MN565259 \\
\hline & HOU1179 & MN541814 & MN541809 & MN541816 & MN565261 \\
\hline & HOU875A & MN541840 & MN541828 & MN541812 & MN551099 \\
\hline Tryblidiopsis pinastri & AFTOL-ID 1319 & - & DQ470983 & - & DQ470935 \\
\hline
\end{tabular}




\section{Phylogenetic analysis}

The sequences, used in this study, included 22 taxa for the ITS matrix, 32 taxa for the LSU matrix, 30 taxa for the mtSSU, and 11 taxa of RPB2. Bisporella citrina (Batsch) Korf \& S.E. Carp. (Helotiales, Helotiaceae) and Neofabraea malicorticis (Cordley) H.S. Jacks. (Helotiales, Dermateaceae) were selected as outgroups. Maximum parsimony (MP) and Bayesian Inference (BI) analyses were performed on the concatenated ITSLSU-mtSSU-RPB2 dataset. Each dataset was first aligned with Clustal X and then manually adjusted to allow maximum sequence similarity in Se-Al v.2.03a (Thompson et al. 1997; Rambaut 2000). Ambiguously aligned regions were excluded from the analysis by hand. Alignments were submitted to TreeBASE under accession number S25247. A partition homogeneity test was performed to determine the congruence of ITS, LSU, mtSSU and RPB2 (Farris et al. 1995; Huelsenbeck et al. 1996). After a positive outcome, the datasets were analysed together. The datasets were prepared and analysed with the maximum parsimony (MP) method using PAUP* 4.0b10 (Swofford 1998). The phylogenetic analysis was conducted using heuristic searches with 1000 replicates of random-addition sequence, tree bisection reconnection (TBR) branch swapping and no maxtree limit. All characters were equally weighted and unordered. Gaps were treated as missing data to minimise homology assumptions. A bootstrap analysis was performed with 1000 replicates, each with 100 random taxon addition sequences. Maxtrees were set to 1000 and TBR branch swapping was employed. For the Bayesian analysis, MrModeltest 2.3 with the Akaike Information Criterion (AIC) was used to choose the best-fit substitution models for the concatenated dataset: GTR+I+G for both ITS and LSU, HKY $+\mathrm{I}+\mathrm{G}$ for $\mathrm{mtSSU}$ and SYM+G for RPB2. The Bayesian analysis was performed with MrBayes 3.1.2 (Huelsenbeck et al. 2011, Ronquist and Huelsenbeck 2003) with two sets of four chains (one cold and three heated) and the Stoprule option in effect, halting the analyses at an average standard deviation of split frequencies of 0.01 . The sample frequency was set to 100 and the first $25 \%$ of trees were removed as burn-in and the remaining trees were kept and combined into one 50\% majority-rule consensus tree. Bayesian Posterior Probabilities (PP) were obtained from the $50 \%$ majority consensus of the remaining trees. Clades receiving both bootstrap values of maximum parsimony $(\mathrm{BP}) \geq 70 \%$ and $\mathrm{PP} \geq 0.95$ were considered to be significantly supported.

\section{Results}

\section{Molecular phylogeny}

The phylogenetic analyses, based on the concatenated four-locus (ITS, LSU, mtSSU, RPB2) DNA matrix, included 32 taxa and 3472 characters, of which 843 were parsimony-informative. The maximum parsimony analysis resulted in one most parsimonious tree with a length (TL) of 2991 steps, consistency index (CI) of 0.697 , retention 
index (RI) of 0.754 and homoplasy index (HI) of 0.303 . Except for the two outgroup species, B. citrina and N. malicorticis, all the other taxa formed one highly supported clade. Lirula macrospora (R. Hartig) Darker resolved as sister to all the remaining taxa (Rhytismatales). This result is similar to the topology of Lantz et al. (2011). The Triblidiaceae samples formed a well-supported clade $(\mathrm{BP}=100 \%, \mathrm{PP}=0.99$; Fig. 1). The type species of Huangshania, H. verrucosa O.E. Erikss., is nested in the Triblidium clade (Fig. 1).

\section{Taxonomy}

\section{Triblidium hubeiense T. Lv \& C. L. Hou, sp. nov.}

MycoBank No: 832358

Figs 2, 3

Diagnosis. Similar to Triblidium sherwoodiae but different by apically not swollen and unbranched paraphyses and homolateral curved ascospores, with a smaller L/W ratio of 1.4-2.3 (average ratio of 1.83) (average ratio of 2.52 for T. sherwoodiae).

Holotype. On dead twigs of Rhododendron sp., CHINA, Hubei Province, Shennongjia National Nature Reserve, 31.4360 N; 110.3014 E, alt. ca. 2900 m, 23 July 2018, C.-L. HOU1350A (BJTC 201908).

Description. Ascomata erumpent from the bark, circular or rectangular in outline, 1.3-2.0 mm diam., solitary or occasionally confluent, with a black (\#211414) outer surface that is sculptured with polygonal areolae, opening by irregular splits to expose a yellow (\#ffc14f) hymenium. In median vertical section, ascomata 500-600 $\mu \mathrm{m}$ thick. Covering stroma 270-300 $\mu \mathrm{m}$ thick near the central part of ascomata, decreasing to $65-110 \mu \mathrm{m}$ at the edge, consisting of an outer layer of highly melanized hyphae with a few remnants of host tissue embedded in the surface and an inner layer of hyaline hyphae. Basal layer 65-160 $\mu \mathrm{m}$ thick, composed of highly melanized hyphae with hyaline hyphae towards the internal matrix of stroma that is $75-125 \mu \mathrm{m}$ thick, composed of textura intricata. Subhymenium 45-75 $\mu \mathrm{m}$ thick consisting of small, irregular textura angularis. Excipulum absent. Paraphyses 200-230 × ca. $1 \mu \mathrm{m}$, filiform, multi-guttulate, guttulae visible in water and IKI but disappearing in both lactophenol solution and 5\% $\mathrm{KOH}$, not swollen and branched at the apex, extending past mature asci. Asci ripening sequentially, 160-200 × 15-24 $\mu \mathrm{m}$, cylindrical, thinwalled, without circumapical thickening, rounded at the apex, 6-8-spored. Ascospores 20-30 $\times 12-18 \mu \mathrm{m}, \mathrm{L} / \mathrm{W}$ ratio of 1.4-2.3 (average ratio of 1.83), ellipsoidal, often curved homolateral, hyaline, at first aseptate, becoming muriform at maturity, with 6-8 transverse septa and a few longitudinal and oblique septa, without a gelatinous sheath, inamyloid in IKI.

Conidiomata and zone lines not seen.

Known distribution. Known from a single collection from Shennongiia National Nature Reserve, Hubei Province, China. 


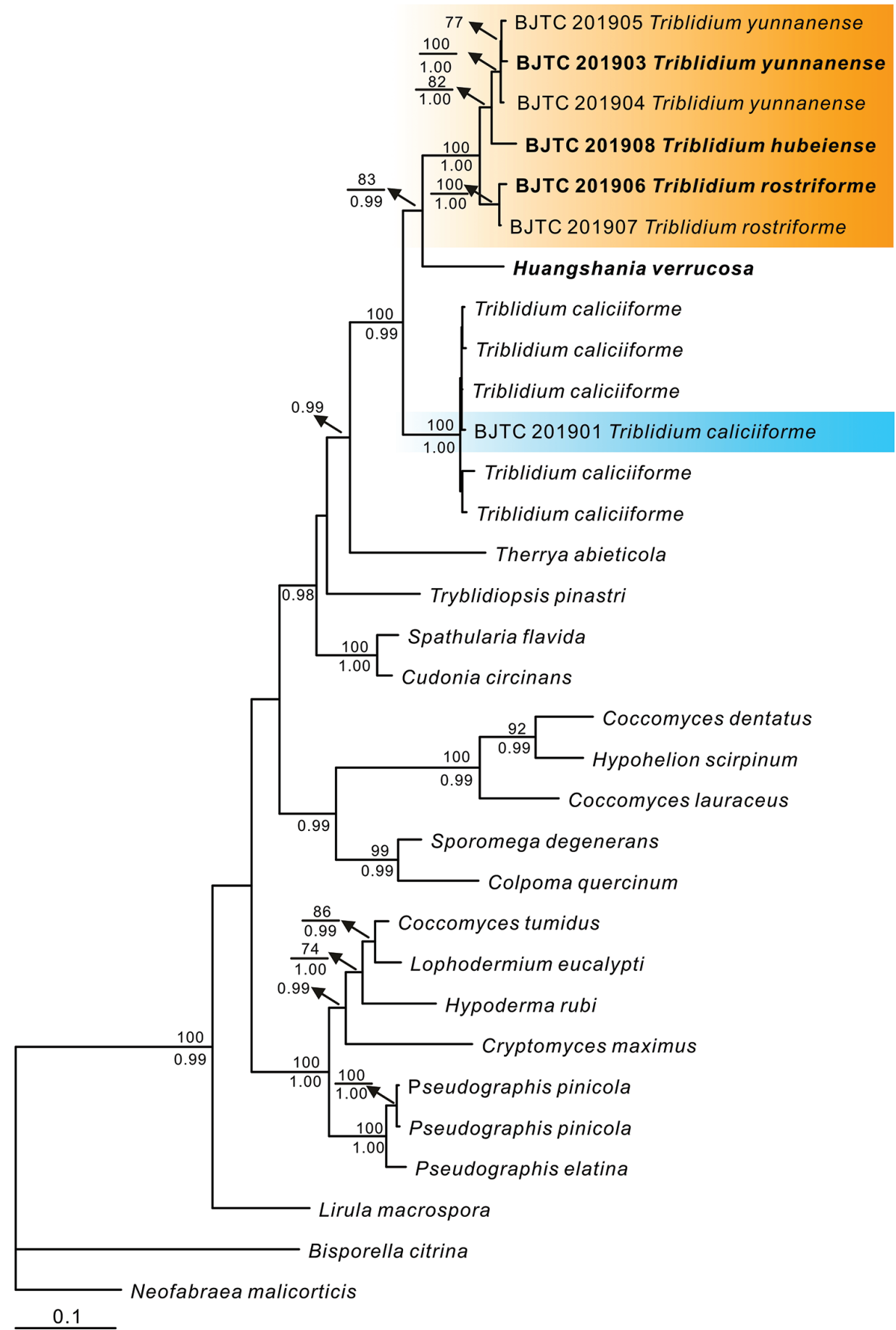

Figure I. A phylogenetic tree generated by maximum parsimony and Bayesian analysis of the combined ITS, LSU, mtSSU and RPB2 sequences, using B. citrina and N. malicorticis as outgroups. Bootstrap values of maximum parsimony $\geq 70 \%$ are shown above the respective branches. Bayesian posterior probabilities $\geq$ 0.95 are marked below the branches. Sequences in bold indicate that the sequences are from the holotypes. 

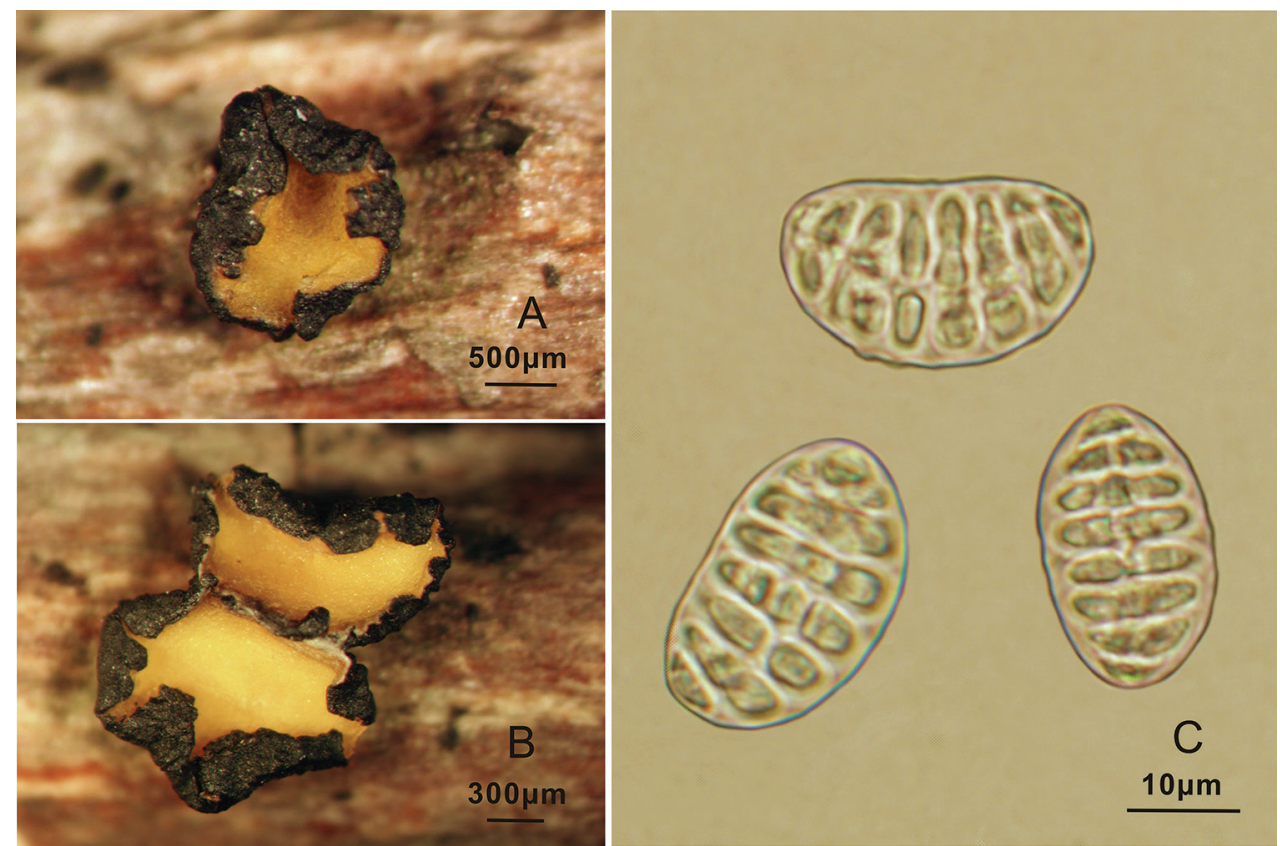

Figure 2. Triblidium hubeiense (Holotype, BJTC 201908) on Rhododendron sp. twig A, B mature dried ascomata observed under dissecting microscope $\mathbf{C}$ dead ascospores in water.
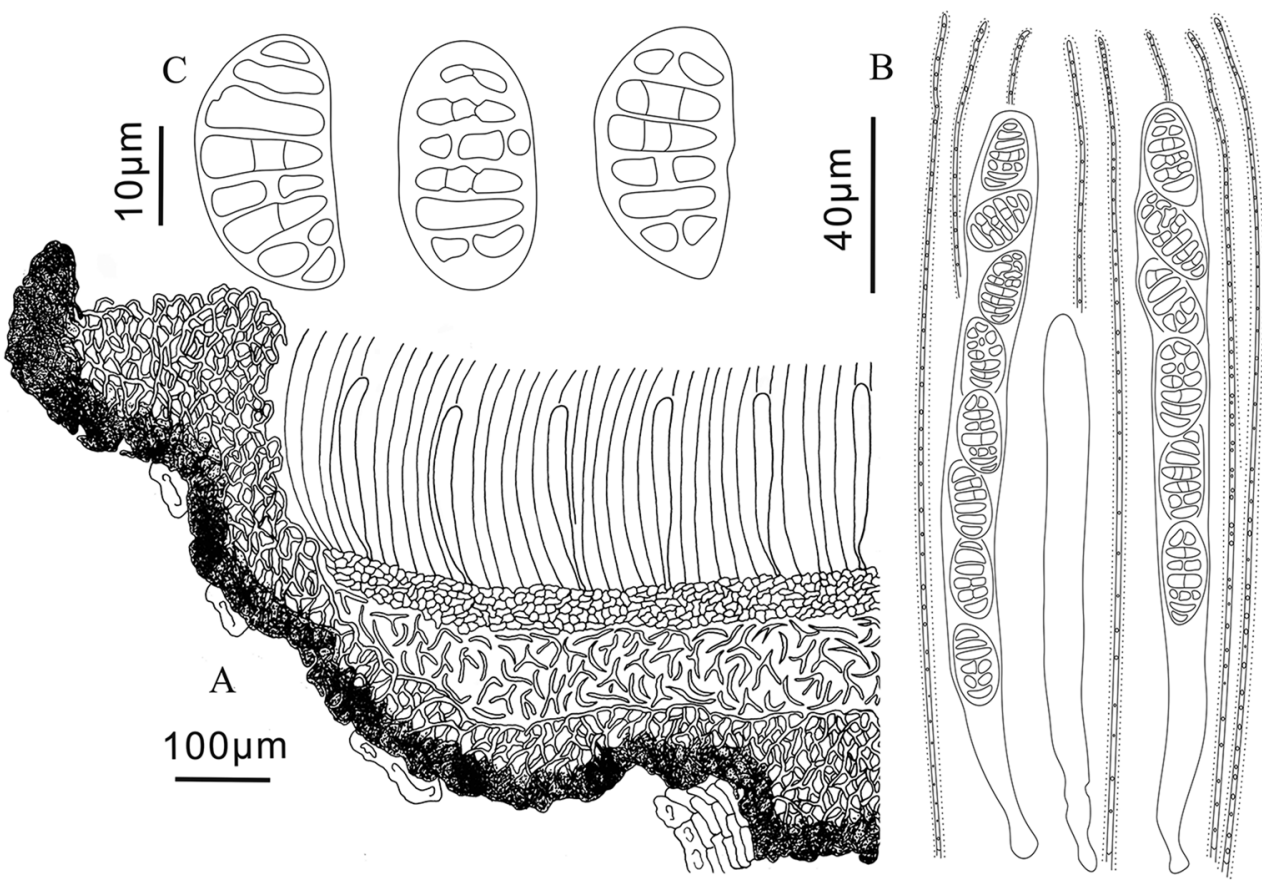

Figure 3. Triblidium hubeiense (Holotype, BJTC 201908) A ascoma in median vertical section B paraphyses, mature asci with ascospores and immature ascus $\mathbf{C}$ dead ascospores in water. 
Etymology. Referring to the Hubei Province where the specimen was collected.

Comments. Triblidium hubeiense is similar to T. sherwoodiae Magnes and T. carestiae (De Not.) Rehm, but T. sherwoodiae has paraphyses with swollen terminal cell, straight ascospores and is only found on Pinus ponderosa; T. carestiae commonly has 3-8 ascospores per ascus, ascospores usually with beak-like structure at poles, 7-14 transverse septa and apically branched paraphyses.

\section{Triblidium rostriforme T. Lv \& C. L. Hou, sp. nov.}

MycoBank No: 832359

Figs 4, 5

Diagnosis. Different from most Triblidium species by producing longer ascospores that have rostriform structures at the poles.

Holotype. On dead twigs of Rhododendron sp., CHINA, Yunnan Province, Lijiang, Laojunshan, 26.6831 N; 99.6997 E, alt. ca. 4056 m, 25 June 2011, C.-L. HOU 889 (BJTC 201906).

Description. Ascomata erumpent from bark, elliptical in outline, $0.85-1.7 \mathrm{~mm}$ diam., solitary, with a black (\#211414) outer surface that is sculptured with polygonal areolae, opening by irregular splits to expose the hymenium. In median vertical section, ascomata 350-550 $\mu \mathrm{m}$ thick. Covering stroma 45-70 $\mu \mathrm{m}$ thick, consisting of an outer layer of highly melanized hyphae with some host tissues incorporated into the surface and an inner layer of hyaline hyphae. Basal layer $40-80 \mu \mathrm{m}$ thick, composed of a lower, highly melanized layer with hyaline hyphae towards the internal matrix of the stroma which is $40-98 \mu \mathrm{m}$ thick, composed of textura intricata. Subhymenium $25-45 \mu \mathrm{m}$ thick, consisting of hyaline textura angularis. Excipulum moderately developed, formed by marginal paraphyses. Paraphyses 180-240 × ca. $1 \mu \mathrm{m}$, filiform, occasionally branched, sparsely guttulate, guttulae visible in water and IKI but disappearing in both lactophenol solution and $5 \% \mathrm{KOH}$. Asci ripening sequentially, $160-220 \times 15-25 \mu \mathrm{m}$, cylindrical, thin-walled, without circumapical thickening, rounded at the apex, 8-spored. Ascospores 35-50 × 12-20 $\mu \mathrm{m}, \mathrm{L} / \mathrm{W}$ ratio of 2.0-3.8 (average ratio of 2.55), elliptical, with rostriform structures at the poles, hyaline, at first aseptate, becoming muriform at maturity, with usually 6 transverse septa and a few longitudinal and oblique septa, without gelatinous sheath, inamyloid in IKI.

Conidiomata and zone lines not seen.

Etymology. From Latin, rostriforme, referring to the beak-like protrusions observed at the ascospore poles.

Additional specimen examined. On dead twigs of Rhododendron sp., CHINA, Yunnan Province, Lijiang, Laojunshan, 26.6702 N; 99.7002 E, alt. ca. 4110 m, 24 June 2011, C.-L. HOU 851A (BJTC 201907).

Comments. Triblidium rostriforme is similar to T. carestiae (De Not.) Rehm but $T$. carestiae commonly has asci with 3-8 ascospores, ascospores with usually 7-14 transverse septa and ramose, multi-guttulate paraphyses. 


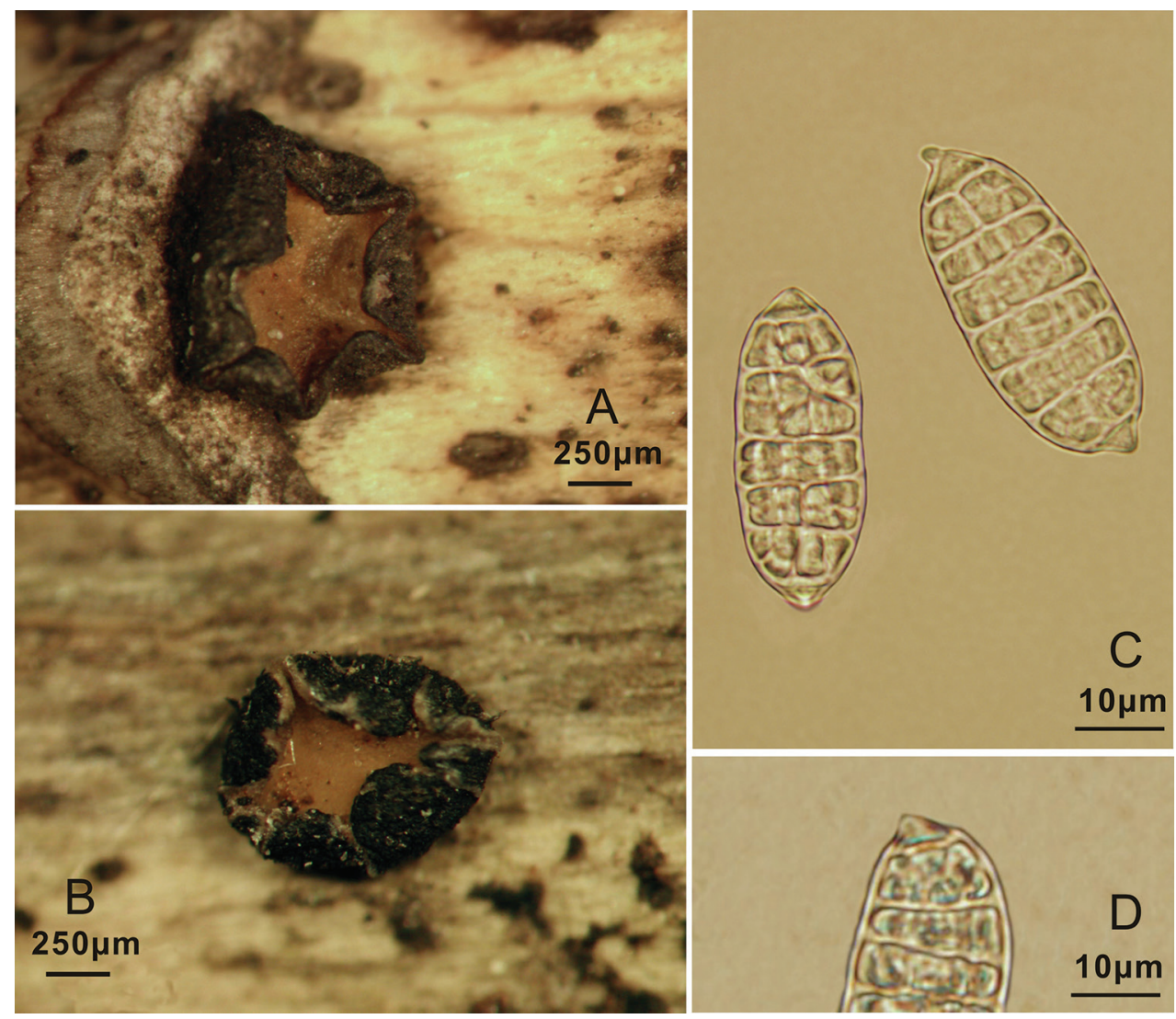

Figure 4. Triblidium rostriforme (Holotype, BJTC 201906) on Rhododendron sp. twig A, B mature dried ascomata observed under a dissecting microscope $\mathbf{C}$ dead ascospores in water $\mathbf{D}$ rostriform structure of ascospores.

Triblidium yunnanense T. Lv \& C. L. Hou, sp. nov. MycoBank No: 832360

Figs 6, 7

Diagnosis. Different from T. hafellneri by its ascospores with 6-8 transverse septa, narrow asci and geographical range. Different from its phylogenetically closest relatives (T. hubeiense and T. rostriforme) by the size and the shape of ascomata and ascospores.

Holotype. On twigs of Rhododendron sp., CHINA, Yunnan Province, Lijiang, Laojunshan, 26.6571 N; 99.6944 E, alt. ca. 4070 m, 25 June 2011, C.-L. HOU 875A (BJTC 201903).

Description. Ascomata erumpent from bark, circular or slightly irregular in outline, 0.5-0.8 mm diam., solitary, with a black (\#211414) outer surface that is sculptured with polygonal areolae, opening by irregular splits to expose the hymenium. In median vertical section, ascomata 300-400 $\mu \mathrm{m}$ thick. Covering stroma 45-75 $\mu \mathrm{m}$, consisting of an outer layer of highly melanized hyphae with remnants of host tis- 

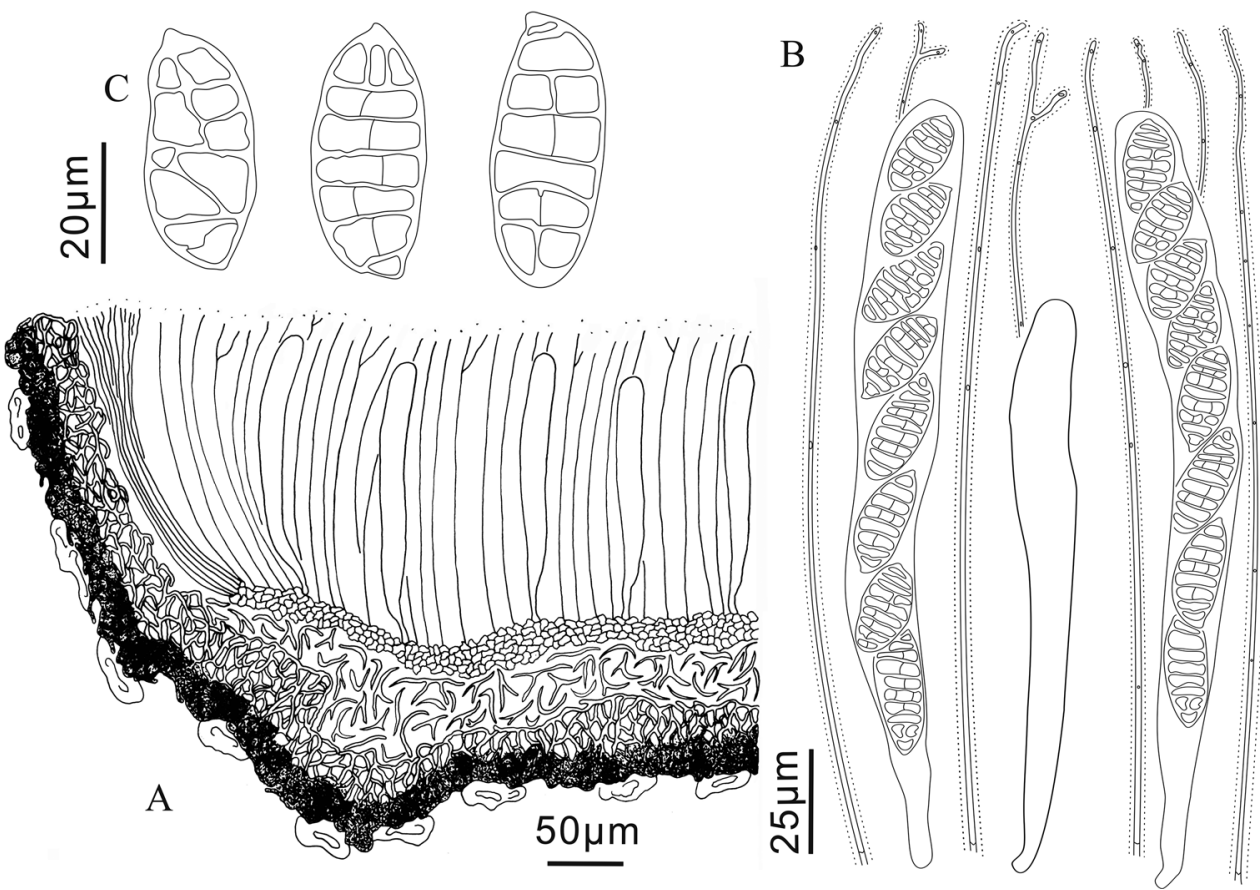

Figure 5. Triblidium rostriforme (Holotype, BJTC 201906) A ascoma in median vertical section B paraphyses, mature asci with ascospores and immature ascus $\mathbf{C}$ dead ascospores in water.

sue incorporated into the outer surface and an inner layer of hyaline hyphae. Basal layer 45-88 $\mu \mathrm{m}$ thick, composed of an outer layer of highly melanized hyphae and short, thick, hyaline hyphae towards the internal matrix of stroma that is $60-85 \mu \mathrm{m}$ thick, composed of thick hyphae. Subhymenium 35-59 $\mu$ m thick, consisting of hyaline textura angularis. Excipulum 25-35 $\mu \mathrm{m}$ thick, formed by marginal paraphyses. Paraphyses 180-230 × 1-1.2 $\mu \mathrm{m}$, filiform, often branched, multi-guttulate, guttulae visible in water and IKI but disappearing in both lactophenol solution and $5 \% \mathrm{KOH}$. Asci ripening sequentially, 150-200 × 13-18 $\mu \mathrm{m}$, cylindrical, thin-walled, without circumapical thickening, rounded at the apex, 6-8-spored. Ascospores 20-30 × 10$15 \mu \mathrm{m}, \mathrm{L} / \mathrm{W}$ ratio of 1.7-2.5 (average ratio of 1.99), ellipsoid, hyaline, at first aseptate, becoming muriform at maturity, with usually 6-8 transverse septa and a few longitudinal and oblique septa, without gelatinous sheath, inamyloid in IKI.

Conidiomata and zone lines not seen.

Etymology. Referring to the Yunnan Province where the holotype specimens were collected.

Additional specimens examined. On twigs of Rhododendron sp., CHINA, Yunnan Province, Lijiang, Laojunshan, 26.6741 N; 99.6930 E, alt. ca. 4040 m, 11 July 2007, C.-L. HOU 470A (BJTC 201904). On dead twigs of Rhododendron sp., CHINA, Sichuan Province, Mt. Emeishan, 29.5185 N; 103.3329 E, alt. ca. 3010 m, 12 July 2014, C.-L. HOU 1179 (BJTC 201905). 

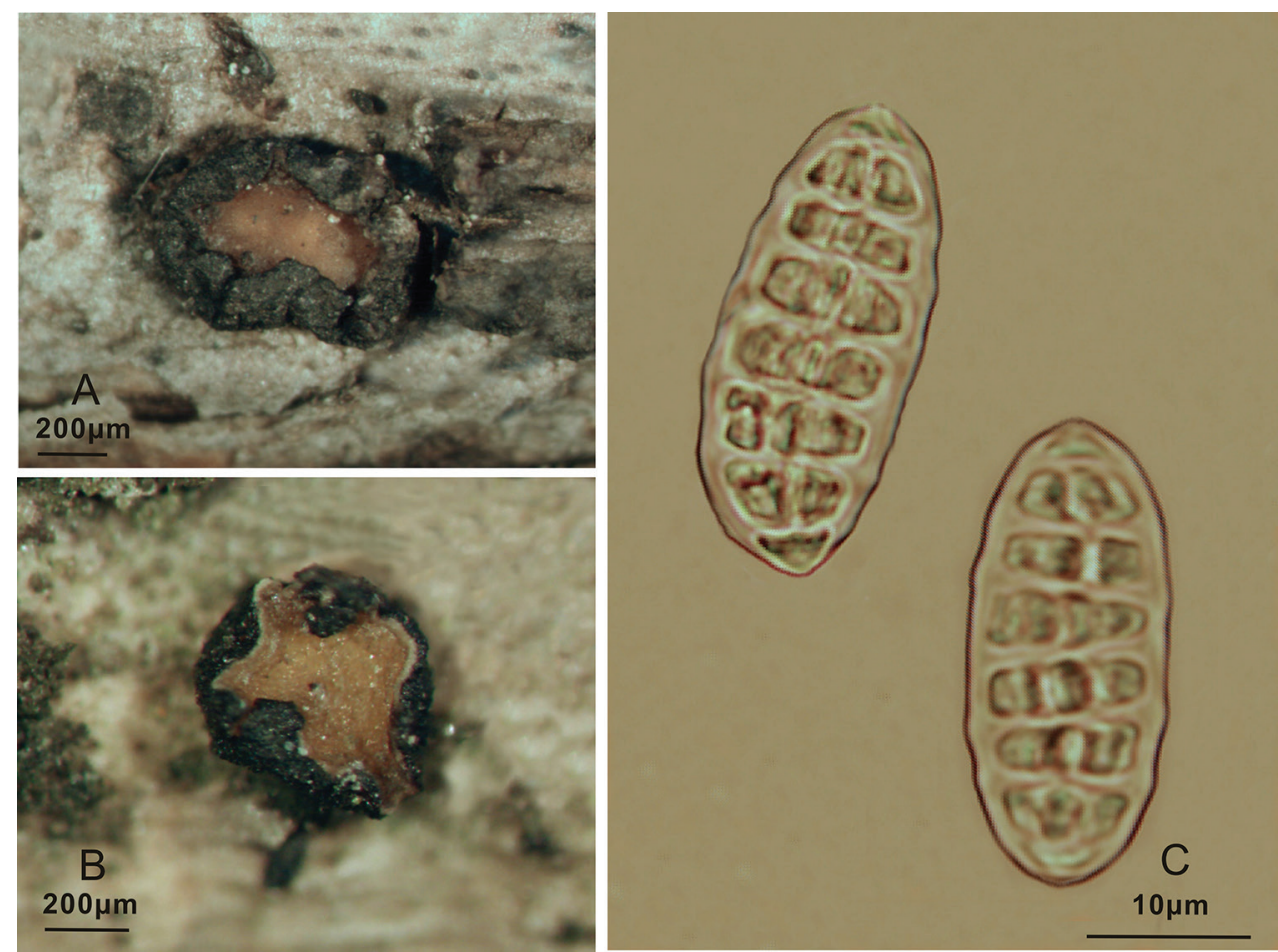

Figure 6. Triblidium yunnanense (Holotype, BJTC 201903) on Rhododendron sp. twig A, B mature dried ascomata observed under a dissecting microscope $\mathbf{C}$ dead ascospores in water.
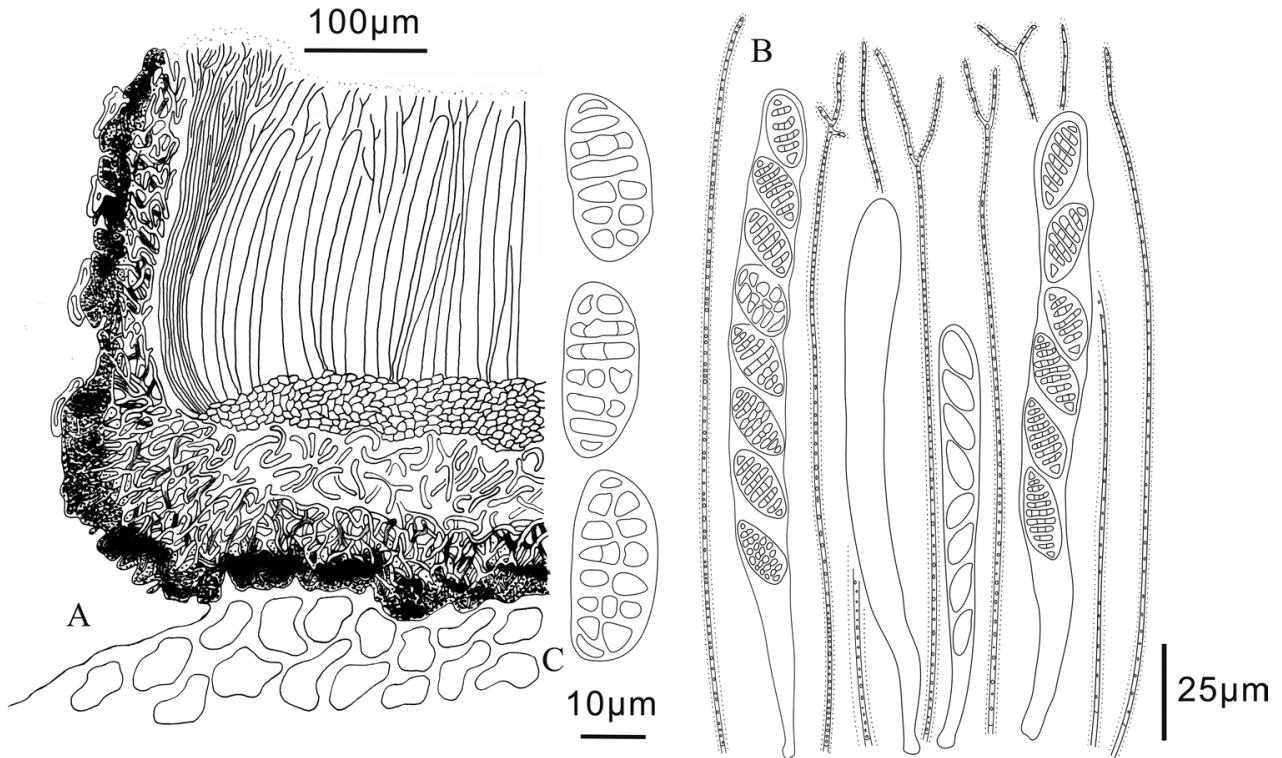

Figure 7. Triblidium yunnanense (Holotype, BJTC 201903) A ascoma in median vertical section B paraphyses, mature asci with ascospores and immature ascus $\mathbf{C}$ dead ascospores in water. 
Comments. Triblidium yunnanense is similar to T. hafellneri Magnes, but the latter has asci 20-25 $\mu \mathrm{m}$ wide, ascospores with 7 transverse septa and occurs on Vaccinum ovatum, Calluna vuglaris, Salix spp., and Nothofagus antarctica in Europe and the Americas. Triblidium yunnanense has a close relationship to the two other new species in this study, but T. rostriforme has larger ascomata, ascospores with special beak-like structures and T. hubeiense has larger ascomata, unbranched paraphyses, a moderately developed excipulum, a thicker covering stroma, basal layer and subhymenium.

Triblidium verrucosum (O.E. Erikss.) T. Lv, C. L. Hou \& P. R. Johnst., comb. nov. MycoBank No: 832361

三 Huangshania verrucosa O.E. Erikss., Systema Ascomycetum 11: 2, 1992.

Notes. The placement of this species in Triblidium is demonstrated by the phylogeny presented in Fig. 1. Eriksson (1992) discussed the similarities between Huangshania and Triblidium in macro-morphology and in the morphology of hamathecial tissues and asci. The two genera differed only in ascospore morphology (elongate-phragmosporous vs. ellipsoidal-muriform). Karakehian et al. (2019) reviewed that ascospore morphology is a poor predictor of relatedness amongst these fungi. Huangshania verrucosa is the type species of the genus, therefore, Huangshania, is synonymized here under Triblidium.

\section{Discussion}

The morphological characteristics of the species described here are typical of Triblidium (Magnes 1997): ascomata on twigs of Rhododendron spp., muriform, inamyloid ascospores, and highly melanized ascomata with roughened outer surfaces. Based on our molecular phylogenetic analyses (Fig. 1), the three newly described species form a highly supported clade, sister to T. verrucosum. Triblidium yunnanense and T. hubeiense form a well-supported subclade sister to T. rostriforme. The similarity of ITS amongst these three new species is $90-95 \%$. The sequences generated from the specimens of T. caliciiforme collected from France on bark of Quercus sp., clustered well with other sequences accepted as T. caliciiforme by Karakehian et al. (2019).

The strongly supported phylogenetic relationship justifying the synonymy of Huangshania with Triblidium was not detected by Karakehian et al. (2019) because only the type species of Triblidium had DNA sequences available. If Huangshania is not placed in synonymy, the addition of the new Chinese Triblidium species described here would result in Triblidium being paraphyletic. The alternative solution, to erect a new genus for the Chinese species, has no morphological support, since these species are very similar to T. caliciiforme in both morphology and ecology. In 1992, Eriksson erected Huangshania as a genus only according to the morphology of the spores. Karakehian et al. (2019) examined the ascospores of $H$. verrucosa and noted 
that ascospore morphology appears to be a poor predictor of phylogenetic relationships amongst these fungi. It is worth noting that the rostrum of the ascospores in T. rostriforme and $T$. carestiae bear some similarity to the plug-like appendages of $H$. verrucosa. Furthermore, we did not transfer $H$. novae-fundlandiae (Rehm) Magnes, another species in Huangshania, to Triblidium since sequences were lacking.

In conclusion, three new Triblidium species from China were described in detail by both morphological and phylogenetic analyses. The new species, discovered in China, illustrate that these fungi are more widespread than previously known. Sequences from these new collections have expanded the representation of this genus in NCBI GenBank and helped our understanding of the family Triblidiaceae. Huangshania is placed in synonymy with Triblidium in order to maintain its monophyly, further demonstrating that ascospore morphology alone may be a poor predictor of evolutionary relationships.

\section{Key to species of Triblidium}

$1 \quad$ Ascospores phragmosporous

T. verrucosum

- Ascospores muriform ..................................................................... 2

2 Ascospores ellipsoid, without rostriform beaks at the poles .......................3

- $\quad$ Ascospores ellipsoid with rostriform beaks at the poles..............................4

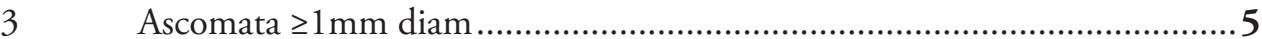

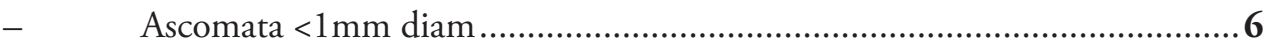

4 Paraphyses multi-guttulate, often branched at the apex; thick-walled asci with 3-8 ascospores; ascospores with 7-14 transverse septa .............. T. carestiae

- $\quad$ Paraphyses sparsely guttulate, occasionally branched at the apex; asci thinwalled with 8-ascospores; ascospores with 6 transverse septa.... T. rostriforme

5 Asci 20-25 $\mu \mathrm{m}$ wide; ascospores with 7 transverse septa; occurring on Vaccinum ovatum, Calluna vuglaris, Salix spp. and Nothofagus antarctica.

T. hafellneri

- $\quad$ Asci 13-18 $\mu \mathrm{m}$ wide; ascospores with 6-8 transverse septa; only found on Rhododendron sp.

T. yunnanense

6 Occurring mainly on Fagaceae spp. and Pinus spp...................................7

- Occurring mainly on Rhododendron spp., asci 160-200 × 15-24 $\mu \mathrm{m}$, ascospores $20-30 \times 12-18 \mu \mathrm{m}$

T. hubeiense

7 Asci $230-280 \times 25-30 \mu \mathrm{m}$, ascospores 30-48 × 12-20 $\mu \mathrm{m} . .$. T. caliciiforme Asci 150-190 × 13-23 $\mu \mathrm{m}$, ascospores 28-35 × 11-14 $\mu \mathrm{m} . .$. T. sherwoodiae

\section{Acknowledgements}

This study was supported by the National Natural Science Foundation of China (No. 31870629 and 31170019). We thank A. Gondiennet for the specimen collection from France. We also thank reviewers Hans-Otto Baral, Jason Karakehian, Donald Pfister and Joey Tanney for patient modification and improvements to the manuscript. 


\section{References}

Eriksson OE (1992) Huangshania verrucosa gen. et spec. nov. (Triblidiaceae, Triblidiales ordo nov.) a discomycete on Pinus from China. Systema Ascomycetum 11(1): 1-10.

Farris JS, Kallersjø M, Kluge AG, Bult C (1995) Testing significance of incongruence. Cladistics 10: 315-319. https://doi.org/10.1111/j.1096-0031.1994.tb00181.x

Gardes M, Bruns TD (1993) ITS primers with enhanced specificity for basidiomycetes-application to the identification of mycorrhizae and rusts. Molecular Ecology 2: 113-118. https:// doi.org/10.1111/j.1365-294X.1993.tb00005.x

Hou CL, Li L, Piepenbring M (2009) Lophodermium pini-mugonis sp. nov. on needles of Pinus mugo from the Alps based on morphological and molecular data. Mycological Progress 8: 29-33. https://doi.org/10.1007/s11557-008-0575-z

Huelsenbeck JP, Bull JJ, Cunningham CW (1996) Combining data in phylogenetic analysis. Tree 11: 152-158. https://doi.org/10.1016/0169-5347(96)10006-9

Huelsenbeck JP, Ronquist F, Nielsen R, Bollback JP (2011) Bayesian inference of phylogeny and its impact on evolutionary biology. Science 294: 2310-2314. https://doi.org/10.1126/ science. 1065889

Johnston PR, Quijada L, Smith CA, Baral H-O, Hosoya T, Baschien C, Pärtel K, Zhuang K-Y, Haelewaters D, Park D, Carl S, López-Giráldez F, Wang Z, Townsend JP (2019) A multigene phylogeny toward a new phylogenetic classification of Leotiomycetes. IMA Fungus 10(1): 1-22. https://doi.org/10.1186/s43008-019-0002-x

Karakehian JM, Quijada L, Friebes G, Tanney JB, Pfister DH (2019) Placement of Triblidiaceae in Rhytismatales and comments on unique ascospore morphologies in Leotiomycetes (Fungi, Ascomycota). Mycokeys 54: 99-133. https://doi.org/10.3897/mycokeys.54.35697

Liu YJ, Whelen S, Hall BD (1999) Phylogenetic relationships among Ascomycetes: evidence from an RNA polymerse II subunit. Molecular Biology and Evolution 16: 1799-1808. https://doi.org/10.1093/oxfordjournals.molbev.a026092

Lantz H, Johnston PR, Park D, Minter DW (2011) Molecular phylogeny reveals a core clade of Rhytismatales. Mycologia 103: 57-74. https://doi.org/10.3852/10-060

Magnes M (1997) Weltmonographie der Triblidiaceae. Bibliotheca Mycologica 165: 1-177.

Prieto M, Schultz M, Olariaga L, Wedin M (2019) Lichinodium is a new lichenized lineage in the Leotiomycetes. Fungal Diversity 94: 23-39. https://doi.org/10.1007/s13225-018$0417-5$

Rambaut A (2000) Estimating the rate of molecular evolution: incorporating non-contemporaneous sequences into maximum likelihood phylogenies. Bioinformatics 16: 395-399. https://doi.org/10.1093/bioinformatics/16.4.395

Rehm H (1888-1896) Die Pilze Deutschlands, Oesterreichs und der Schweiz. III. Abtheilung: Ascomyceten: Hysteriaceae und Discomyceten. Dr. L. Rabenhorst's Kryptogamen-Flora von Deutschland, Oesterreich und der Schweiz ( $2^{\text {nd }}$ edn.) Bd 1: Abt. 3. Leipzig, Verlag von Eduard Kummer, 1275 pp. https://doi.org/10.5962/bhl.title.1356

Rehm H (1912) Zur Kenntnis der Discomyceten Deutschlands, Deutsch-Österreichs und der Schweiz. Berichte der Bayerischen Botanischen Gesellschaft zur Erforschung der Heimischen Flora 13: 102-206. 
Rehner SA, Samuels GJ (1994) Taxonomy and phylogeny of Gliocladium analysed from nuclear large subunit ribosomal DNA sequences. Mycological Research 98(6): 625-634. https://doi.org/10.1016/S0953-7562(09)80409-7

Ronquist F, Huelsenbeck JP (2003) MrBayes 3: Bayesian Phylogenetic inference under mixed models. Bioinformatics 19: 1572-1574. https://doi.org/10.1093/bioinformatics/btg180

Swofford DL (1998) PAUP*: phylogenetic analysis using parsimony (and other methods). Version 4. Sinauer Associates, Sunderland.

Thompson JD, Gibson TJ, Plewniak F, Jeanmougin F, Higgins DG (1997) The ClustalX windows interface: flexible strategies for multiple sequence alignment aided by quality analysis tools. Nucleic Acids Research 24: 4876-4882. https://doi.org/10.1093/nar/25.24.4876

Vilgalys R, Hester M (1990) Rapid genetic identification and mapping of enzymatically amplified ribosomal DNA from several Cryptococcus species. Journal of Bacteriology 172: 4238-4246. https://doi.org/10.1128/jb.172.8.4238-4246.1990

White TJ, Bruns TD, Lee S, Taylor J (1990) Amplification and direct sequencing of fungal ribosomal RNA genes for phylogenetics. In: Innis MA, Gelfand DH, Sninsky JJ, White TJ (Eds) PCR Protocols, a Guide to Methods and Applications. Academic Press, San Diego, 315-322. https://doi.org/10.1016/B978-0-12-372180-8.50042-1

Zoller S, Scheidegger C, Sperisen C (1999) PCR primers for the amplification of mitochondrial small subunit ribosomal DNA of lichen-forming ascomycetes. Lichenologist 31: 511-516. https://doi.org/10.1006/lich.1999.0220 